\title{
Corruption in Cameroon: Public Perception on the Role and Effectiveness of the Different Anti-Corruption Agencies
}

\author{
Bechem Emmanuel Egbeyong ${ }^{1,2 *}$ \\ ${ }^{1}$ University of Warwick, Coventry CV4 7AL, UK \\ ${ }^{2}$ University of Buea,P.O.BOX 63 Buea, South West Region, Republic of Cameroon
}

\begin{abstract}
Corruption is a phenomenon with serious consequences that affects all communities in the world. In Cameroon, its effects are widespread in the Public and Private sectors. Cameroon has twice been classified as the most corrupt state in the world-1998 and 1999 as per Transparency International indices. The government has put several structures in place to fight this ill, but the population is yet to clearly understand. A study was therefore carried out to determine the public's perception of the roles and effectiveness of the different anti-corruption agencies. Semi-structured questionnaires were administered to the public in Buea. Interviews were conducted with some workers of the major anti-corruption agencies. Respondents agreed that corruption was a major problem and that its existence was due to lack of transparency, no accountability, greed, inadequate sensitization on its consequences. The notorious sectors were the police, gendarmerie, education, customs, treasury, taxation and judiciary. They identified the National Anti-Corruption Commission, Special Criminal Court and Supreme State Audit Office as popular anti-corruption agencies. The public is aware of the ills of corruption and they also understand government's efforts towards its eradication. The roles of these anti-corruption institutions were however, not known by most of the respondents.
\end{abstract}

Keywords: Corruption; Anti-corruption agencies; Cameroon

\section{Introduction}

'Corruption' originates from the Latin word-corrumpere, which means 'bribe, mar or destroy' [1]. Much evidence suggests that it has been around the world from time immemorial, and, in recent times, it has occupied a front seat in global discussions [2]. In spite of its presence everywhere, there exists no universally accepted definition of corruption, and this constitutes one of the principal difficulties in studying the phenomenon [3]. While corruption is mostly described as the abuse of public power for private gain (a definition used by the World Bank) $[4,5]$ moralists describe corruption as "an immoral and unethical phenomenon that contains a set of moral aberrations from moral standards of society, causing loss of respect for and confidence in duly constituted authority" [6]. Despite the differences in the definition of corruption from the public-centred to the market-centred perspectives, and from the revisionist to moralist perceptions, there is however unanimity in the condemnation of corruption which is a global predicament that hinders economic growth, threatens the integrity of markets, undermines fair competition, distorts resource allocation, destroys public trust, and cripples the rule of law [7].

Corruption is a 'virus' [8] that poses a threat to global socioeconomic and political advancement, thus a universal antidote would be most suitable to counteract its propagation. In this light, numerous international symposiums and conventions have focused on the eradication of corruption across the world through the creation of institutions and the utilisation of diverse instruments ranging from the enactment of domestic and international laws, to the endorsement of global cooperation in tracking and sanctioning perpetrators of corrupt practices. These include among others; the 1996 Organization of American States Inter-American Convention Against Corruption; the 1997 Convention on the Fight against Corruption involving Officials of the European Communities or Officials of Member States of the European Union (This Convention was adopted by the Council of the European Union); the 1997 Organization for Economic Co-Operation and Development (OECD) Convention on Combating Bribery of Foreign Public Officials in International Business Transactions; the 2003 African Union convention on Preventing and Combating Corruption; the United Nations Convention Against Corruption
(UNCAC); Leader's declarations at G20 summits (See Pittsburgh 2009, Toronto 2010, Seoul 2010, Cannes 2011, Los Cabos 2012, and St. Petersburg 2013) and the Financial Action Task Force (FATF) which has as mission, to set standards and promote effective implementation of legal, regulatory and operational measures for combating money laundering, terrorist financing and other related threats to the integrity of the international financial system [9].

The proliferation of institutions charged to combat corruption saw the rise of Transparency International, a global Non-Governmental Organisation (NGO) founded by Peter Eigen in 1993 (Berlin, Germany) to collaborate with governments, businesses, and the civil society organizations to put effective measures in place to tackle corruption. Transparency International ranks countries annually based on a Corruption Perception Index (CPI). This method of measuring corruption is equally used by the World Bank's Control of Corruption Index which is based on cross-country perception of corruption [10]. Transparency International is present in over 100 countries around the world, among which is Cameroon- a developing sub-Saharan African country that has been ravaged over the years by corruption. Corruption has been identified as a serious drawback to Cameroon's quest for emergence in 2035 [11], and President Paul Biya went on to stress that, 'It is corruption that for the greater part of it, compromises the success of our efforts... The embezzlement of public funds, whatever the form, is a crime against the people who are deprived of the resources that belong to them [12]. This resulted in the creation of numerous anti-corruption organs to effectively combat corruption and allow for meaningful and

*Corresponding author: Bechem Emmanuel Egbeyong, University of Warwick, Coventry CV4 7AL, UK, Tel: + 44 (0)24 7657 4036, Email: b.emmanuel@gmail.com

Received December 29, 2017; Accepted January 06, 2018; Published January 12, 2018

Citation: Bechem EE (2018) Corruption in Cameroon: Public Perception on the Role and Effectiveness of the Different Anti-Corruption Agencies. Review Pub Administration Manag 6: 235. doi:10.4172/2315-7844.1000235

Copyright: () 2018 Bechem EE. This is an open-access article distributed unde the terms of the Creative Commons Attribution License, which permits unrestricted use, distribution, and reproduction in any medium, provided the original author and source are credited. 
durable development. Nonetheless, the organisation and functioning of the different units assigned to tackle corruption in Cameroon have been heavily scrutinized by members of the public, who often crossexamine the role played by the different institutions, and question their effectiveness.

The study reported here was therefore aimed at establishing the popularity and efficiency of the prominent anti-corruption bodies in Cameroon, based on public perception. This will be done by presenting a background to the fight against corruption in Cameroon so as to ate the reader within the context, an explanation of the research methodology adopted and the findings thereof, and finally linking the results to the role played by the institutions involved.

\section{Background}

Corruption is a canker worm that has invaded the Cameroonian society. It cuts across all sectors in Cameroon, be they the Public or Private sector and, not even the church is free of corruption [13]. It is an age-old phenomenon that has plagued the Cameroonian society notably in the Health, Educational, Judicial, Financial, Military, and in the Law and Order departments. Cameroon has twice topped the chart of the most corrupt states in the world-1998 and 1999 as per Transparency International indices [14]. Corruption is manifested in several forms including; bribery, nepotism, graft, fraud, speed money, theft, pilferage, embezzlement, falsification of records and influence peddling.

Corruption (commission or omission) is punishable under section 134 of the Penal Code of Cameroon: It indicts "Any national, foreign or international civil servant or public employee, who for himself or for a third party solicits, accepts or receives any offer, promise, gift or present in order to perform, refrain from performing or postpone any act of his office. Also indicted under this section is anyone who receives a reward as remuneration for having already performed or refrained from performance of an act. The popular notion of a corrupt person suggests that only the 'receiver' is corrupt. However, this is far from the truth as the 'giver' commits no lesser evil. The Cameroonian Penal Code goes as far as punishing the corruptor. It provides that, "Whoever makes promises, offers, gifts and presents or yields to requests liable to result in corruption in order to obtain the performance, postponement or abstention from an act or one of the favours or benefit ... shall be punished in a like manner as under section 134(1) above whether corruption produced its effects or not". Other sections of the Penal Code punishing corruption in the public service include; s.137 (Indulgence), s.142 (Undue demand), s.160 (Compulsion of public servant), s.161 (Procuring Influence), s.312 (Corruption of employee), and s.184 (Misappropriation of public funds).

The classification of Cameroon as the most corrupt nation in the world in 1998 and 1999, made the government more willing than ever to fight the ill. The slogan "Corruption kills the nation" was adopted by the government in its fight against corruption [14]. The national newspaper - Cameroon Tribune had a column devoted every day to corruption. The aim of this campaign was to educate Cameroonians on the ills of corruption and the potential damage it could do to the nation if it persisted. Government media actively engaged in the denunciation of acts of corruption in all sectors of public and private life, with the state newspaper - Cameroon Tribune - championing the battle by examining the illicit swelling of bills in Administrative services, graft in Educational facilities, the Police and the army, customs, health institutions, post and telecommunications services and the railway company among others.
In the early 1990s, Garga Haman Adji the then Minister in charge of Supreme State Audit and Public Service waged a war against embezzlers of state funds. He went as far as submitting names of corrupt officials to the Presidency, requiring that they be punished. The sum of funds embezzled totalled 357 million francs CFA. The response he got was rather discouraging as his Ministerial portfolio was modified, limiting his competence to civil service and administrative reforms. He thus lost his authority over the Supreme State Audit. He resigned from government believing that the modification was due to his hard-line stance against corruption [15].

In as much as this primary phase of the fight against corruption had its weaknesses, a number of achievements were recorded. These included; the arrest and sentencing of certain high-profile embezzlers such as Professor Titus Edzoa (former SG of the Presidency) and Michel Thierry Atangana by the Mfoundi High Court.

The advent of the $21^{\text {st }}$ century brought about changes in the fight against corruption which was until then, predominantly handled by local courts. Several institutions were created to combat this crime in Cameroon. The very first of these was the National Anti-Corruption Observatory created in 2000 following pressure mounted on the Cameroonian government by the US State Department, the Bretton Woods Institutions and Transparency International [16]. Lack of financial and structural autonomy marred the functioning of this institution, thereby leading to its replacement with the National AntiCorruption Commission (NACC, known by its French acronym CONAC) in 2006. Since its creation, CONAC has led the fight against corruption mainly via investigation of corrupt officials and transmission of the reports to the Presidency to visa the prosecution of the criminals.

Aside CONAC, the office of Supreme State Audit is also a leading body in the fight against corruption in Cameroon today. In 2011, a Special Criminal Court was created to prosecute State officials who misappropriated funds valued equal to or above fifty million francs CFA. Since then, several top state officials including a former Prime Minister, Minister of State in charge of Territorial Administration and Decentralization, Minister of Finance and numerous General Managers of public enterprises and parastatals have been convicted by this court for em funds [17]. These are clear indicators that the advent of the $21^{\text {st }}$ century brought about a drastic change in the government's fight against corruption in Cameroon. The "Operation Sparrow Hawk" was launched by the President of the Republic and placed under the coordination of the Vice Prime Minister, Minister of Justice, and Keeper of the Seals, to track down and expose public servants who misappropriate state funds [18]. These institutions were created to jointly and severally uproot corruption which hinders development as it accounts directly and indirectly for loss of revenue by the government. It is also important to highlight that the fight against corruption in Cameroon does not exist only in the public sector, but also in the private sector. The results of a survey carried out in 2008 showed that $49 \%$ of the 1052 companies interrogated affirmed to have bribed taxation officers [19]. Another $76 \%$ of those companies agreed that corruption had negatively affected their businesses.

The Inter-Patronal Organization of Cameroon (GICAM) and the Business Coalition against Corruption (BCAC) are examples of institutions which combat the practice in the private sector. BCAC for example, fights against corruption principally by educating company personnel on the essence of a corrupt free business environment. Over 200 companies were sensitized on the fight against corruption in Cameroon as at 2015 [20]. Similarly, GICAM signed two memoranda of understanding (MOU) with CONAC on $11^{\text {th }}$ November 2014 
Citation: Bechem EE (2018) Corruption in Cameroon: Public Perception on the Role and Effectiveness of the Different Anti-Corruption Agencies. Review Pub Administration Manag 6: 235. doi:10.4172/2315-7844.1000235

wherein GICAM agreed to carry out sensitization within the private sector on the fight against corruption [21]. Transparency International on its part does not end at sensitization, but goes even further as to investigating and openly denouncing acts of corruption. It also evaluates the government's efforts in the fight against corruption and establishes an annual overall rating of corruption in the world.

The current president of the NACC-Dieudonné Massi Gamsargues that for an effective combat against corruption, there has to be Mobilisation, Participation and Engagement by both society and government [22]. By mobilisation, he means that those at the forefront of the fight have to ensure that there is constant sensitization. It also includes the preparation of personnel within the different services to sensitise the users. Participation calls for the implication of every Cameroonian. It requires that all experiences and expertise should contribute towards activities relating to the fight against corruption. He proposes that when setting up anti-corruption units, all the different categories of people within that service should be represented. Engagement is a promise by each and every person to take part in the fight against corruption. He argues that where there is a greater engagement by members of a unit, then corruption has no place [23].

According to Dieudonné Massi Gams, the trinity of mobilisation, participation, and engagement stipulates that only a powerful coalition can guarantee a more effective fight against corruption. He also calls for better education on corruption, sanctioning of the perpetrators, moral restoration, and the enforcement of anti-corruption laws.

\section{Research Methodology}

This study was carried out in the town of Buea, the capital of the South West Region of Cameroon. The town is found in the eastern slopes of the second highest mountain in Africa, Mount Cameroon. Buea is the seat of the first Anglo-Saxon university in Cameroon, the University of Buea. Several other private higher educational institutions are located in Buea.

The research reported here employed both the doctrinal and empirical methods of information gathering. It made use of both primary and secondary sources of information. The primary sources included penal laws against corruption as well as those creating the different anti-corruption bodies, legislation appertaining to their organogram and modus operandi, and also decided cases in the fight against corruption. The secondary sources also included law reports, books, newspapers, and related published materials.

The research equally made use of semi-structured questionnaires, which were administered to a cross-section of members of the Buea community, to ascertain public awareness on the role and efficiency of the institutions involved in the fight against corruption in Cameroon. The questions in the questionnaire were formulated so as to permit us obtain information on the respondent's perception on the roles and effectiveness of the various anti-corruption agencies. These questionnaires were administered randomly to people of different age groups, gender and societal class, to permit for greater insight of the awareness of government's efforts in the fight against corruption in Cameroon. A total of 320 questionnaires were administered.

Interviews were also conducted with some personnel of the Supreme Court's Audit Bench, the Special Criminal Court, Supreme State Audit office and CONAC, all located in Yaoundé, the capital of Cameroon. This was to get first-hand information on the roles of these different institutions and to better appreciate their actions in the anticorruption campaign.

\section{Findings}

Of the 320 semi-structured questionnaires administered, 250 of them were completed and returned to us. The success rate for the completion of the questionnaire therefore stood at $78.13 \%$. The questions were grouped into three sections based on content; demographics (age, sex, gender, level of education of respondents), knowledge on corruption and awareness on the fight against corruption.

\section{Demographics}

Of the total number of respondents, majority $(155,62 \%)$ were males, while 95 (38\%) were females (Figure 1).

The age of the respondents ranged from 16-57 years old. Most (35\%) of them were within the 21-30 years age bracket, while the least were in the over 50 years age class (Figure 2).

Most of the respondents were highly educated with their educational level ranging from holders of University degree (130) to those who had just a First School Leaving Certificate (12) (Figure 3).

\section{Knowledge on corruption}

In assessing public perception of the role and effectiveness of State institutions and Transparency International in the fight against corruption in Cameroon, the second part of the questionnaires set out to evaluate public knowledge on corruption. The participants were

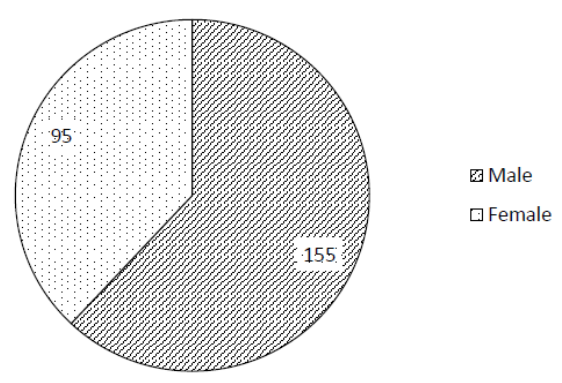

Figure 1: Proportion of respondents based on gender.

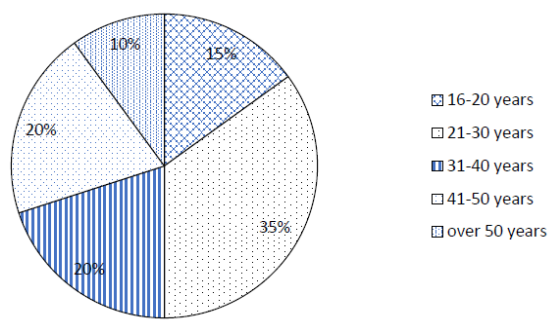

Figure 2: Age class of respondents.

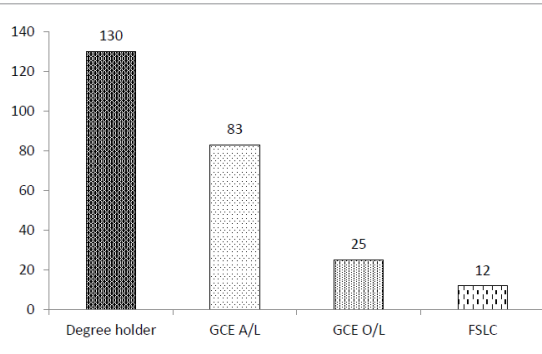

Figure 3: Educational qualifications of respondents. 
primarily asked whether or not corruption is a problem in Cameroon. The overwhelming answer from all respondents was an unequivocal 'YES'. This was followed by interrogating the respondents on the causes and effects of corruption on the individuals, their communities and Cameroon as a whole. The causes of corruption in Cameroon were largely attributed to lack of transparency and accountability in the public service, greed, and lack of sensitization on the ills of corruption. The most cited effects were poverty and low living standards, underdevelopment, and brain drain as skilled labourers travel abroad to places where competence takes precedence over corrupt practices. Also, participants were called upon to identify the sectors which they felt were most affected by corruption. The most notorious and frequently cited sectors by the public were; the Police force and Gendarmerie, the Educational sector, Customs, Treasury, Taxation, and Judiciary.

\section{Awareness on the fight against corruption}

To test public awareness on the fight against corruption in Cameroon, participants were invited to comment on their awareness of government's fight against corruption, its efficiency, and the weaknesses of the campaign to stamp out this malpractice. They were also asked to state any institutions they know were involved in the fight, and comment on the role they think the institution in question plays. The greater number of participants acknowledged that they were aware of government's efforts in the fight against corruption, but however, went on to denounce the ineffectiveness of the institutions involved. The results of the survey indicated that CONAC was the most popular participatory body, followed by the Special Criminal Court and the Supreme State Audit office. Transparency International enjoyed minimal popularity meanwhile the lesser known Supreme Court's Audit Bench and the National Agency for Financial Investigation (ANIF) occupied the bottom of the chart. It would be important to indicate that from the findings of this study, the roles of most institutions involved in the fight against corruption were largely unknown (except for CONAC and the Special Criminal Court). Moreover, a simple majority of those who were cognisant of the duties of these anti-corruption bodies went on to decry the proliferation of institutions charged to stamp out corruption stating that "too many cooks spoil the broth".

\section{Information on the roles of some anti-corruption agencies}

In carrying out this research, interviews were conducted with officials from the prominent anti-corruption bodies, all of which have their headquarters in Yaoundé. As expected, it was impossible to filter any sensitive information as to what concerns the fight against corruption in Cameroon from any of the officials outside what is known to the public. Nonetheless, from the interview conducted at the Special Criminal Court, the correspondent authority indicated that previously there existed a Special Criminal Court in Cameroon charged with the prosecution of those guilty of the embezzlement of funds that plagued the cocoa industry in the 1960's [24]. This Court was dissolved by Ordinance No 72/04 of $26^{\text {th }}$ August 1972 on Judicial Organization in Cameroon, upon completion of its mission. At the Supreme State Audit Office, the correspondent official lamented on the duplicity of functions of the anti-corruption agencies and decried the lack of coordination among the different actors. While the interviewee at CONAC complained about the lack of resources, the authority at the Supreme Court's Audit Bench regretted the limitations of the powers of the Court as it is restricted from prosecuting those indicted by its reports.

\section{Discussion}

Corruption is a phenomenon whose effects are felt by all, irrespective of gender, age, or social class. In the study reported here, $62 \%$ of the respondents were males with only $38 \%$ being females. Efforts are being made to get women actively involved in the fight against corruption. In this light, Transparency International in March 2015 decided to unite with women to fight corruption [25].

Furthermore, a study carried out in Ghana by Transparency International revealed that $67 \%$ of the inhabitants of the country argue that they have never encountered a woman who used her position to extort money and favours. In a similar survey effectuated in Sierra Leone, $73 \%$ of the citizens believe there would be less corruption if more women were in power.

Statistics drawn from the survey reported in this paper indicate that most applicants were young people (35\%), and also highly educated (130 respondents). These qualities allowed for a greater insight into the public perception on the status of Cameroon's fight against corruption, given that young people are the most exposed group to the ill as they strive to get educated, open small businesses or seek employment. Moreover, the high education level of persons within the $21-30$ years age bracket is indicative of the quality replies gotten from the questionnaires.

The institutions charged with fighting corruption in Cameroon have recorded remarkable success over the years. CONAC has actively been engaged in mass sensitization campaigns and the organisation of anti-corruption forums such as the 2008 symposium to discuss corruption in the transport sector. This forum comprised of CONAC coordination committee members, representatives of administrations and organizations in charge of transport and also, representatives of trade unions. The principal purpose for the forum was to come up with effective solutions as to how to curb corruption that had ravaged the sector [26]. Among the many resolutions, it was decided that mixedcommissions would be set up to control and evaluate the driving school formations, driving school exams and attribution of driving licenses, the respect of chronology in the enumeration of driving licenses and certificate of capacity, the dismantling of networks of démarcheurs, and respect of texts and legislation with regards to highway transport. A similar symposium was held for the education sector, and numerous decisions were arrived at. Nonetheless, the impact of these sensitization campaigns remains minimal as the same old malpractices that had plagued both sectors still exist today.

The Supreme State Audit Office on its part has indicted numerous state dignitaries in its reports, many of whom have been jailed for embezzlement. The Supreme State Audit boasts of having helped the state to economise 35 billion FCFA in the realisation of major projects [27]. It is a similar story on the side of the National Agency of Financial Investigation (known by its French acronym-ANIF) and the Supreme Court Audit Bench, which have transmitted reports to hierarchy indicting several authors of corrupt practices. Nonetheless, it is regrettable to consider the fact that both institutions do not have the powers to press for charges on those indicted by their investigations suo motu. The Audit Bench draws up and publishes annual reports on State accounts to be submitted to the Head of State.

One of the sectors heavily gangrened by corruption is that of public contracts. The process of tendering public contracts is often marred by corruption as the biggest bidder and not necessarily the most competent wins the contract. To this effect, the Public Contract Regulatory Board (known by its French acronym-ARMP) was set up to oversee the regulation, follow-up, and evaluation of the public markets sector in order to curb corruption. According to statistics from the data 
bank of the ARMP, the agency has helped some 9411 business actors, managed some 4080 tenders, and allocated 4310 contracts to the tune of 590,056,887,714 FCFA.

In an attempt to clampdown on widespread embezzlement in the public service, the Special Criminal Court (SCC) was created with jurisdiction to entertain embezzlement cases where the amount in question was equal or superior to fifty million francs CFA. In presenting a bulletin of the SCC in 2014 at the National Assembly, the Justice minister indicated that CFA 2.401.235.610 have been duly paid in. This amount represents the reimbursement of corpus delicti by some defendants who applied for discontinuance of proceedings. He stated that sixteen persons had benefitted from this measure as at that date, including former Minister in charge of Basic Education, Haman Adama [28]. More recent convictions of this court include the fifteen years' imprisonment sentence of Dayas Mounoume, former Director General of the Douala Port Authority, Arsene Essomba the former Deputy Director and Abel Maguieb Agbor, ex Administrative and Financial Director of the Port for embezzlement of 458 million francs CFA [29]. In October 2015, former Director General of Cameroon's Airports (Aeroports du Cameroun, ADC) was given a 30 years' imprisonment sentence by the Special Criminal Court for mismanaging the sum of one billon, six hundred and forty-two million francs CFA. It is important to note that although incarcerated since 2010, Ntongo Onguene had already been sentenced in 2013 to 20 years of imprisonment. Among the notable cases of the Special Criminal Court, is the sentencing of Ephraim Inoni, former Prime Minister of Cameroon and Marafa Hamidou Yaya, long-time collaborator of the President of the Republic.

Despite registering significant results in recent times, Cameroon's fight against corruption is far from over. The reason for this lies in the weaknesses that have plagued the anti-corruption movement. The lack of political will which is visible in the non-enforcement of Article 66 of the Cameroonian constitution demanding the declaration of wealth by public authorities has contributed to the resilience of this virus. Also, the lack of independence and the overshadowing role of the executive over anti-corruption units compromises the smooth functioning of these organs. This can be seen in the judicial organisation of Cameroon wherein the President of the Republic heads the Higher Judicial Council (HJC), which is the organ in charge of nominating, promoting and sanctioning members of the judiciary. Fombad argues that the executive in Cameroon, has always had and still retains absolute control over the judiciary through the appointment of judges and allocation of the budget for the justice department [30]. This mode of operation has often led to criticism of the sincerity of the fight against corruption, notably the 'Operation Sparrow hawk'. The selective nature exhibited by the SCC in prosecuting those indicted by reports of the Supreme State Audit Office, CONAC and the Audit Bench has led a cross-section of the Cameroonian public to consider it as a means of settling political scores [31].

Transparency International on its part has not been left out of the anti-corruption drive. In July 2011, TI-C launched a campaign tagged L'éducation primaire publique au Cameroun: entre la mal gouvernance et l'illusion de la gratuité. The principal goal of this campaign which regrouped such prominent members of the clergy, media houses and the civil society like Christian Cardinal Tumi, Kareyce Fotso, Foly Dirane and Richard Kings amongst others was to underline the illegal payment of fees at public primary schools by struggling parents, whereas no fees are to be paid [32]. To come out with this analysis, TI-C had to interview over 1400 persons, principally Head Masters of the said institutions and other administrative staff, parents, and some pupils of the handpicked institutions. The results of this survey showed that each parent pays an average sum of 20,000 F CFA in illegal fees for the education of their children at the public primary schools yearly. TI-C among other recommendations, called for a greater respect of the texts governing the organisation and execution of the primary school budget. Aside from the education sector, TI-C has also carried out surveys in different sectors, notably elections, the private sector, and the police, coming up with varied recommendations to permit for a more effective fight against corruption.

\section{Conclusion}

Based on the data recovered from the survey, it is safe to say that there exists a considerable level of public awareness of the fight against corruption in Cameroon. Nonetheless, the role played by the different institutions involved remains ambiguous to many, while their effectiveness is often heavily scrutinized. Corruption leads to further indebtedness of the country [33], brain drain as skilled labour exits to seek greener pastures [34], hampers economic growth [35], and results in poverty and low living standards. These conditions have been made possible by the absence of a strong political will to curb corruption [36] ambiguity surrounding the roles and functioning of the different anti-corruption organs [37], and lack of independence of these institutions [17].

Considering the above observations drawn from the survey, youths and women constitute a major powerhouse in the governments strive to curb corruption. The institutions charged to fight corruption should be given greater financial and administrative autonomy to wage an effective war against corruption.

\section{Acknowledgements}

I would like to thank all the respondents and the interviewees who participated in this survey. I would also like to thank Mr. Nguni Alain for his guidance during the survey.

\section{References}

1. Crouch T (2012) I, Cinna (The Poet) Oberon books London, UK.

2. Tanzi $\vee(1998)$ Corruption around the world: Causes, consequences, scope and cures. MF Staff Papers, 45: 559-594.

3. Jain AK (2001) Corruption: A review. J Econ Surv 15: 71-121.

4. Senturia JJ (1931) Encyclopaedia of social sciences, Vol. IV.

5. Robin T (1990) Corruption, development, and underdevelopment. Durham, North Carolina: Duke University Press 11: 34-35

6. Gould DJ (1991) Administrative corruption: incidence, causes, and remedia strategies. In: Farazmand A (ed). Handb Comp Dev Public Admin 467-480.

7. G20 Leaders declaration (2012) Los Cabos, Mexico, USA. pp. 77-80.

8. Forsberg P, Severinsson K (2013) The Corruption virus: Intertwining theories for detailed information on how scholars have used the virus metaphor to make statements on corruption.

9. http://www.fatf-gafi.org/about/

10. Olken BA, Pande R (2012) Corruption in developing countries. Ann Rev Econ Ann Rev 4: 479-509.

11. The president of the republic of cameroon (2011) Economic emergence action

12. Special communication of H.E. Paul Biya (2017) President of the republic of Cameroon.

13. Lang MK (2014) The Patterns of corruption in Christian churches of Cameroon: The case of the presbyterian church in Cameroon. SAGE Journals, USA. pp. 31: 132-144.

14. GERDDES-Cameroon (1999) "Corruption in cameroon". Friedrich-EbertStiftung, Germany. 
Citation: Bechem EE (2018) Corruption in Cameroon: Public Perception on the Role and Effectiveness of the Different Anti-Corruption Agencies. Review Pub Administration Manag 6: 235. doi:10.4172/2315-7844.1000235

15. Fonchingong, TN, Gemandze JB (2009) Cameroon: The stakes and challenges of governance and development.

16. Ndikum G (2001) Cameroon's anti-corruption campaign: a paper tiger? Global corruption report 2001, Transparency International.

17. Nguemegne JP (2011) Fighting corruption in Africa: The anticorruption system in cameroon. Int J Org Theor Behav 14:83-121.

18. Monde Afrique (2015) Cameroun: L'impitoyable machine judiciaire de Paul Biya, Cameroon

19. Afrique L (2011) Cameroun: Quelle stratégie de lutte contre la corruption au sein de l'administration publique? .

20. Cameroon Web (2015) 200 companies sensitized against corruption in Cameroon.

21. Cameroon Web (2014) Private sector sign up to the fight against corruption.

22. Dieudonné Massi Gams (2014) lutte contre la corruption et restauration morale au Cameroun, Yaoundé, éditions, 39.

23. Talla M (2013) Deux Ans de Mise en Oeuvre de la Strategie Nationale de Lutte Contre la Corruption au Cameroun: synthese d'un processus inedit, Yaoundé, CLE.

24. Hervé Magloire Moneboulou Minkada (2012) Le Tribunal Criminel Spécial au Cameroun et les Grands Principes de la Justice Criminelle: Étude comparative sur les Lois de 1961 et 2011.

25. Transparency International (2015) Uniting with women to fight corruption.
26. Rapport sur l'état de la lutte contre la corruption au Cameroun (2011) CONAC 27. BBC Afrique (2014) Cameroun: les institutions en conflit.

28. Jeune Afrique (2013) Cameroun: l'ex-ministre Haman Adama libre après avoir restitué des fonds détournés.

29. All Africa (2015) Cameroon: Ex-Douala ports authority GM jailed for 15 years.

30. Fombad CM (2000) Endemic corruption in cameroon: Insights on consequences and control. In: Hope KR, Chikulo BC (eds) Corruption and development in Africa. pp. 234-260.

31. Mbock CG (2011) L'Opération Epervier au Cameroun: Un Devoir d'Injustice. Kiyikaat Editions.

32. Transparency international Cameroon (2012) L'éducation primaire publique au Cameroun: entre la mal gouvernance et l'illusion de la gratuité.

33. Cooray A, Dzhumashev R, Schneider F (2016) How does corruption affect public debt? An empirical analysis, World Development.

34. Ariu A, Squicciarini MP (2013) The balance of brains: Corruption and migration. EMBO Reports, 14: 502-504.

35. Angang $\mathrm{H}$ (2002) Public exposure of economic losses resulting from corruption China \& World Economy Number 4: 44-49.

36. Onga T (2012) Cameroon's War: The fight against impunity. A normative analysis. Antrocom Online J Anthropol, 8: 103-122.

37. Atangana PR (2012) Corruption and structural reforms in cameroon. Res World Econ 3: 7-13. 